\title{
How to Reduce Employee Turnover Intention in Retail Environment? Role of Off-the-Job Embeddedness
}

\author{
Stacy Lee and Jung Ha-Brookshire, University of Missouri, USA
}

Keywords: Retail, Off-the-Job embeddedness, Employees, Turnover Intention

Employment in the retail industry overall grew by approximately $12 \%$ by adding 1.8 million jobs in 2011 (Lockard \& Wolf, 2012). Although such job demand is increasing, many retail workers are employed part-time, and $62 \%$ of employees are between the ages of 16 and 44 (Bureau of Labor and Statistics, 2012). A significant portion of them are college students with part-time appointments. Overall, the retail industry had a 33.5\% turnover rate in 2014 (Bureau of Labor and Statistics, 2014). The high turnover rates incur additional costs of recruiting and training new employees, while customer satisfaction may decrease. Despite the importance of retail employees for retailers' customer service and potential sales, studies on retail employee retention have been limited in the apparel retail management literature.

Mitchell, Holtom, and Lee (2001) defined job embeddedness as a broader constellation of factors (on-the-job and off-the-job) influencing employee retention, including three types of attachment: (a) link - the extent to which employees have links to other people or activities; (b) fit - the extent to which their jobs and communities are similar to or fit with the other aspects in their life spaces; and (c) sacrifice - what they would give up if they leave a job. That is, the more embedded employees are in both the organization and in the community, the more likely they will remain at their current job. Although many studies have been done about the role of job embeddedness in many industries and contexts, little research is available on how job embeddedness affects retail employees' employment intention. Therefore, this study aimed to explore off-the-job embeddedness and its impact on turnover or employment intention for employees in retail environment - especially part-time retail employees who may view their current jobs as temporary.

Due to the explanatory nature of this study, a semi-structured, in-depth interview method was chosen because it is useful for investigating situations, using a variety of different perspectives and for studying research problems little of which is known (Creswell, 2005). The study sample was selected through a purposive sampling technique to select people who possess specific characteristics in order to illuminate the phenomenon being studied. Each interview session took approximately 20-30 minutes. A total of 8 participants were recruited via a university campus news info advertisement. Participants' age ranged between 20 and 29 with approximately one and half years of retail experience. All of them were working more than 20 hours but less than 40 hours weekly. The interview data were transcribed and interpreted to find key themes.

The results show that all participants saw retail employment as temporary. One described, "I would stay but definitely not a long term. Maybe a year or two." That is because they perceived

Page 1 of 2

(C) 2015, International Textile and Apparel Association, Inc. ALL RIGHTS RESERVED ITAA Proceedings, \#72 - www.itaaonline.org 
that retail jobs were transitional or temporary and something to have before a future career starts. Consistent with the literature, off-the-job embeddedness seemed to play a vital role in turnover intention. Five out of 8 participants put a great importance on links for their employment and turnover intention, as "not having support from friends and family" is a big issue and they "will go back to where [they were]" as soon as they can. Fit-to-community (or lack of) was also important for employment (or turnover) decision; as one said, "I feel no connection to this city. There isn't much personality to this community." This lack of fit experience even seemed to affect their future employment sites; as another said, "I don't want to ever live in East coast where you walk by someone and they don't ever wave or make an eye contact with you." This lack of fit-to-community also influences a quality of relationship at work; as a participant said, "I don't have those good relationships with coworkers and I don't like to deal with customers." Across the participants, who were clearly willing to move on from retail employment whenever opportunity knocks, the sacrifice that they will have when they leave seemed very slim.

Overall, the results showed that the participants consider retail employment as temporary or short-term solutions while they are transitioning from college to professional careers. What is important to note here is the fact that participants do not feel connected to co-workers, communities, and even customers. Therefore, the quality of relationship at work and customer service suffers, which can be detrimental to the overall success of retail businesses, as retail employees are the ones who interact with customers daily. Retail businesses must develop ways for these employees to feel connected and engaged by creating fun activities or events in and outside the work. Making these employees feel like part of the community and company must be a key strategy to get them excited about their jobs and, therefore, their performance. Without these employees' success, retail business will not succeed. Perhaps, management environments where they could feel at home could be something to pursue for overall retail success.

\section{References}

Bureau of Labor and Statistics (2012). Current Population Survey. Retrieved March 12, 2015 from http://www.bls.gov/web/empsit/cps_charts.pdf

Bureau of Labor and Statistics. (2014). Job Openings and Labor Turnover - December 2014. Retrieved March 7, 2015 from http://www.bls.gov/news.release/pdf/jolts.pdf

Creswell, J. W. (2005). Educational research: Planning, conducting, and evaluating quantitative. Upper Saddle River, NJ: Pearson Prentice Hall.

Lee, T. W., Mitchell, T. W., Sablynski, C. J., Burton, J. P., \& Holtom, B. C. (2004). The effects of job embeddedness of organizational citizenship, job performance, volitional absences, and voluntary turnover. Academy of Management Review, 47, 711-722.

Lockard, C. B. \& Wolf, M. (2012). Employment outlook: 2010-2020: Occupational Employment Projections to 2020. Retrieved March 11, 2015 from http://www.bls.gov/opub/mlr/2012/01/art5full.pdf

Mitchell, T.R., Holtom, B.C., \& Lee, T.W. (2001). How to keep your best employees: Developing an effective retention policy. Academy of Management Executive, 15(4), 96109.

Page 2 of 2 